\title{
THE EFFECT OF NATURE IN THOMAS HARDY'S POETRY
}

\author{
Liwaa Ahmed Abdullah', Rafed kawan Mohammed ${ }^{2}$ \\ \{liwaaalkhazraji@gmail.com, Rafedkawan51@gmail.com\} \\ Ministry of Education ${ }^{1}$, I'mam Aladham Gollege ${ }^{2}$
}

\begin{abstract}
This research aims to discover the effect of Nature in Thomas Hardy's chosen literary works. The treatment of Hardy's ecology illustrates the roots of thought that have led to our contemporary environmental crisis. Hardy shares affinity by philosophically reconstructing society in the center of natural elements and images by introducing the true meaning of literary art and nature. Hardy self-consciously depicts the naked reality of nature, property, and the place of man as a reaction towards a mechanized and materialized culture that values technological innovations and expositions politically. Hardy has distinguished nature with his distinctive style and insight. Analyzing the work of Hardy helps to know the social and ecological critiques of Victoria on the relationship between the human environment that are biologically and psychologically fascinating and strange when it comes to placing humans into the universe. The research demonstrates how someone such as Hardy represented his knowledge of nature as a mere reflection of man's harmony or disharmony with his climate. Hardy promotes the belief that setting is an important and fundamental factor of human lives that has a direct effect on their lives consciously and unconsciously. Discussing different characters and their various attributes and functions concerning the natural world around them are of great importance for understanding the link between man and the environment. Hardy not only depicts in his novels but also in his poetry the portrayal of the true position of man in nature and the significance of this representation in human life.
\end{abstract}

Keywords:

effect of Nature, literary work, Thomas.

Article Received: 18 October 2020, Revised: 3 November 2020, Accepted: 24 December 2020

\section{INTRODUCTION}

Most students are interested in Hard's poems and novels especially the use of nature. So I chose this topic to help those who are interested in Hard's life and poems and who want to know about Hard. The most important aim in these papers to make the light shines on the effect of nature in Hard's poetry to help the students who want to study this aspect. The study of nature is restricted to nature in Hard's poetry only. So the treatment will be limited to the use and effect of nature.

The value of the study of nature in the present study will be good and helpful for those who are interested in Hardy's work.

Finally, the paper has three sectionsin section one. I took about Hardy's life, in section two I took about Hardy's sense of nature. And section three about a conclusion.

\section{Hardy's Life}

Thomas Hardy was born on June 2, 1840. His father Thomas (1811-1892), In the parish of Stinsford, east of Dorchester, a hamlet, was a mason and local builder in Dorset in England, Where Jemima (born 1813-1904) married his mother, and his dad at Beaminster at the end of 1839. He was a poet and an English novelist. Jemima had a good reading, and at the age of eight,she taught Thomas before he went to Bock Hampton, his first school. Several years in the making, he studied Latin and showed his academic ability at the Young Gentlemen Academy in Dorchester. Because of the lack of university opportunities in Hardy's family, his formal education ended at the age of seventeen when he trained as a local architect James Hicks. In London, Hardy never felt at home, so he was so conscious of class inequalities and his social inferiority. He was involved in social change and the work of John Stuart Mill during this period. In 1870, Hardy encountered and loved Emma Gifford, he was married in Kensington in the autumn of 1874 While 
on an architectural project to restore St Juliet's parish church in Cornwall. In 1885, Thomas and his wife moved to Max Gate, a house that Hardy and his brother built and designed. Though later strangled, Emma's eventual Death had a dreadful influence on him in 1912, After her death, Hardy went to Cornwall to revisit places related to her judicial life., reflecting on his death in his poetry from 1912-13. In 1914, his 39-year-old secretary, Florence Emily Dug dale, married Hardy.

Hardy was appalled by the devastation caused by the First World War. "I do not think a world in which such fiendishness is possible to be worth the saving" and "better to let western 'civilization' perish, and let the black and yellow races have a chance. - He wrote to John Galsworthy that the exchange of international thought is the only possible salvation for the world". In December 1927, Hardy suffered from pleurisy, and just following 9 p.m. on January 11, 1928, he died at the Max Gate after dictating his last poem to his wife on his deathbed.

Although Hardy wrote poetry all his life, considering himself mainly as a poet, his first collection was only published in 1898 .

He was inspired by romanticism both in his novels and in his poetry, William Wordsworth in particular.

\section{The Victorian Period}

Queen Victoria married Prince Albert of SaxeCoburg-Saalfield, a German relative, in 1840. and the United Kingdom was reigned by her son, William IV. It was a very happy marriage.

The key characteristic of Victorian politics, both the individual and society, is the desire for change and progress. There were three strong forces at work.

first, the rapid growth of the middle class effectively displaced the aristocracy's complete influence. Their code was respectable-a businessman had to trust and had to avoid scrupulous gambling and heavy drinking.

SecondA theological reform closely related to evangelical Christianity and included in that of
Lord Shaftesbury (1801-1885) both noncompliant sects as Methodists and in particular the evangelist or Low Church aspect in the developed English Church. It placed upon society new moral principles, such as the observance of Sabbath, duty, widespread charity, home discipline,For the smallest shortcomings and needs for improvement, and self-examination. In the 1790s, evangelical moralists began with the anti-slavery movement and established a highly popular method for increasing the moral sensitivities of all family members and reaching the public through severe, well-coordinated agitation and propaganda.

The thirdEffects originated from Jeremy Bentham (1748-1832), James Mill (17731836), and John Stuart Mill (1806-1873), his uncle, the philosophical utilitarian's. They were not moral, they were empirical. Their movement also referred to as "Philosophic Radicalism," was a formulation for endorsing "progress" with scientific logic and business efficiency in defining, evaluating, and finding solutions to social problems.

\section{Hardy's Work}

Although his first collection was not published until 1898, Hardy wrote poetry throughout his life and considered himself mainly as a poet. Initially, he became established as a writer of novels like Far from the Madding Crowd (1874), The Mayor of Caster bridge (1986), Tess of the Urbervilles (1891), and Jude the Obscure (1895). Throughout his life, Hardy's poetry was admired by younger poets (particularly the Georgians), who regarded him as a mentor. His poetry was lauded by Ezra Pound, W. H. Auden, and Philip Larkin after his death.

Hardys Wessex was founded in the semi-fictional area of Wessex and was founded on the medieval English-Saxon kingdom. Hardy's Wessex was gradually incorporated in the counties of Dorset, Wiltshire, Somerset, Devon, Hampshire, and many of Berkshire, both in Southwest and South Central British. Two of his novels, Tess of the $d$ 
'Urbervilles and Far from the Madding Crowd, were included in the BBC survey, The Big Read.

\section{Hardy's Sense Of Nature}

Hardy's sense of nature was too complicated and extensive, nature is not merely a background to human wills and actions. It is continually changing and attracts man's lifeat point after point. He saw nature more than setting or landscape or basis of revelation and beauty; He saw it intensely as a whole network of forces or causes and effects with a man should try to reconcile. Hardy found no comfort in the possibility God is blind and not the action's judge. Hardy concluded nature also can cause mankind catastrophe.The ideas and experiences in his poetry are lucidly conveyed and these ideas are not old-fashioned or out of mood with the time in which he lived.

In subject matter, he deals with fate. There are also nature poems that describe improbability Hardy found in nature the same sort of beauty.

Hardy was bam as a poet even his novels are the works of the poet. He considered poetry to be his true vocation in life. He began composing poems before he had written even a single line is present. He went on writing poetry.

He was both a scientist and poet, As a poet,he loves the beauty of nature, but as a scientist does not inner its faults. He was conscious of the ephemeral nature of her spring shows enjoys the sweet music of birds of nature but also knows that it was shortlived. He gares us both sides of nature the ugly as well as the beautiful, the bright as well as the dark. He portrays completely. In his love of nature there is nothing mystic or transcendental as in that of word worth, though, he habitually personifies nature objects, he never believes that nature has separate life, us out of her own.

He loves nature for her beauty, and not for only mysticquantities that she might hare. He does not worship her as a kind and benevolent goddess watching over those whose souls are in harmony with her soul. He is too much of a realistic to care for such a romantic.

\section{Comets On Hardy's Poems}

Hardy's poem Heiress and Architect may help his views on man and nature and the best human life. The poem is an allegory of human desire crushed by the realities of existence. The "Heiress" represents any aspiring gown person as a hopeful successor of life, where is the "'Architect"' stands for a reason ", adeeply skilled " master of the revelations of science as well as the real facts of the human condition.

The dialogue opens with the "Heiress " romantic dream of building a house which she intends to welcome natural beauty, joy, then love and finally meditation, but the "Meh designer" reminded her of the fact that she must also proper for "'securing pain" disillusionment and death. The debate continues on these terms, the idealistic expectations versus the positive truth. The heiress longs to live close to wells wor thioun nature or cheerfully and contentedly or in lovers or oven the quiet life are clues.

The poem is an elegy, mourning those who used to live in the house and now in halite "Ahighnew house " the house of death, with the simplest of domestic details, a picture is built up of house ordinary in its significance, asis loose. Each stanza has a season, beginning with winter the first implied that the moving house takes place in autumn which is preceded by spring and summer consequently, for so many things the season of change.

The last one of each stanza gives a wider background symbolic of transcience and death, to the picture of present grief. It sets against the background of eternal nature and ineluctable present.

The industrial revolution, agriculture digression, and the change in the village caused the end of rural England;Therefore; most of the habitats of the united kingdom come to live in the urban district

After finding their way to the capital most of the rural people became vagrants, suffered a lot of poverty because they didn't find even a place for sleeping. Then it seemed possible for the lower and 
middle. Class families to keep their discipline under these severe circumstances.

Hardy's novels focused around Dorchester, which was very barren and historically terrified. His novels bravely questioned many of the Victorianage theological confrontations and went on to offer an insight into the human condition. In the early 1860s, after Darwin appeared in space in 1859.

The trust of Hardy was always surprised. However, he soon embraced the mechanical, determined view of cruelty representing his ineradicable tragic and self-destroying character fates.

\section{To whom read about nature}

Hardy continued the self-help education he began reading extensively again immersing himself in the work of, Horace, Thackeray's new man. He was dedicated out a direct and reading in his lodgings the same time he has been reading the work of the socialist Francois fours, so he wrote about the mysterious relationship between nature and man There is also in the most contradictory sense of mystically significant face of nature have placed on nearly every page he wrote.

\section{Conclusion}

Thomas Hardy before he was a novelist, he was a poet he had extremely succeeded to create poem enriched with the flavor of love and nature with humanity. He was generous to portray maturity in many poems, that faces theapproval of readers and entities as equally.

Hardy had done well log employing natural objectsto express a general idea about mankind, and what nature could do to exploit human beings. We can conclude that Hardy chose nature in certain poems as atopic because of the spirit of the Victorian era influence of Romanticism upon Victorian poets. So he chose nature as an atopic to convey feelings and ambitions.

On the other hand, we can conclude that the engagement with the woman in love which leads to marriage eventfully, discovered that she relates to him by blood ! that made him pessimistic, choosing nature as a topic for poetry and refuge. Finally, many conditions surrounded him, he chose nature as atopic for the verse to be a refuge and leads to be far from the problem which had been done by the industrial revolution.

\section{Reference}

[1] Alexander, Micheal.(1973) A History of English literature . London: Antony Rowe tld, chippen ham, wilts.

[2] Al -Tukmacky .s. (1997) The Quest for Artistic integrity between meliorism and pessimism, a study in selected poems of Thomas Hardy. M. A.thes is university of Baghdad.

[3] Crireghton,T.R. M (1977) poems of Thomas Itardy. London . The macmillan press Hela.

[4] Hardy Thomas (1974) Encyclo peadia Britanica $15^{\text {th }}$ edition .r.8.

[5] Taylor, R.H (1977) the personal, note books Thomas Hardy . London ,Macmillan pressltd .

[6] Woll man , M . (1975) The twentleth century poets Bristo western pointiy . service London .

[7] https://en.wikipedia.org/wiki/Thomas _Har dy.

[8] https://en.wikipedia.org/wiki/Victoria n_er

a. 